\title{
Land Grabbing and the Gendered Livelihood Experience of Smallholder Farmers in Northern Ghana: Through a Human Development and Capability Lens
}

\author{
Gideon Kofi Agbley \\ Department of Social, Political and Historical Studies, \\ University for Development Studies \\ Email:dr.gagbley@uds.edu.gh \\ DOI//http://dx.doi.org/10.4314/gjds.v16i1.8
}

\begin{abstract}
The phenomenon of land grabbing in developing countries has led to worsening livelihood choices for smallholder farmers who depended on communal lands for subsistence. While previous analyses of land grabs were framed in a paradigm that emphasised outcomes, this study is framed within a human development approach which places emphasis on both outcomes and procedural concerns. The procedural concerns are in relation to representation prior to and during negotiations for land acquisitions. The study is based on analysis of in-depth interviews and focus group discussions to assess BioFuel Africa Limited's investments in two communities in northern Ghana. Results show the company is no longer operating its jatropha (jatropha curcas) plantation and therefore the inability to provide jobs promised. Meanwhile the clearing of large contiguous tracts of lands have had devastating impacts on the livelihoods of women and men. The study revealed that there was poor participation of women in all stages and processes of the land acquisitions for the project, and that the land acquirer had failed to fully implement the procedural concerns of equity, efficiency, participation and sustainability in the acquisitions of lands for the project. It is recommended that large-scale land deals should be conditioned on proper disposal and utilization of lands within specified time frames, failure for which land is reverted to original use.
\end{abstract}

Keywords: Land Grabs, Equity, Efficiency, Participation, Sustainability 


\section{INTRODUCTION}

The security of communal land tenure systems and the livelihood choices that such land entitlement rights provide smallholder farmers in northern Ghana have seriously been threatened by foreign business such as BioFuel Africa in search of new destinations of investment for secured returns. Following the global food and energy crises of 2008, 2009 and 2010 (World Bank, 2014) there is a focus of capital towards investment opportunities in emerging markets and new frontiers. The attractions had been for investment in large-scale food agriculture and for biofuel feedstock (Boamah, 2014). The argument made in favour of large-scale land acquisition is that it brings in much needed foreign direct investment at the national level, boosts export and growth and creates jobs at the local level (Razavi, 2014; Tsikata \& Yaro, 2011). The analysis of the impact of land acquisition is often framed within a neoliberal economics framework. Neoliberal economics is not adequate in explaining the peasant way of life and the importance which smallholder farmers attach to their land. It does not explain the many useful ways that smallholder farmers have built their way of life around communal lands. Often, smallholder farmers are disadvantaged by being pushed away from community land on which they had depended over the millennia. They have either been unfavorably pitched against large-scale agribusiness interests or overly dependent in an unsustainable manner on jatropha farms.

The phenomenon of large-scale land grabs displaces the usufructuary rights often afforded by communal lands while the farming systems employed are environmentally unsustainable compared with the agro-forestry farming systems adopted by smallholder farmers. The farming system adopted by large-scale land acquirers is to remove all trees on the land in order to maximize productivity. Such a method of farming destroys the important linkages between the forest and the farm, leading to forest degradation and exacerbating the problem of food insecurity (Bhaskar, Wildburger \& Mansourian, 2015). In northern Ghana, the impact on women of such activities manifests through the harvesting of forest foods, shea nut processing and charcoal-making industries. Such activities are often reserved for or are engaged in by women (Apusigah, 2009). While women bear most of the brunt of the dispossession of communal lands, they are not involved in the negotiations leading up to the acquisition and development of lands. Moreover, plantation companies tend to employ mostly men in the development and maintenance of the field (Yaro, 2013; Tsikata \& Yaro, 2011). Studies on the effects of land grabs have been over-reliant on outcomes only, while ignoring key procedural concerns (Wisborg, 2012; Daley \& Pallas, 2014; Yamano et al., 2009). Events and outcomes, although important as they are, do not provide adequate informational sources and needs 
to be combined with procedural concerns such as processes in pre-acquisition, acquisition and post-acquisition related issues.

The literature on land reforms and land deals has revealed analysis based on aspects of procedural concerns but not the whole spectrum of human development. Wisborg (2012) has looked at sustainability while participation (and empowerment) has been the focus of work by Daley and Pallas (2014). Efficiency and equity issues have been researched into by scholars from a more quantitative tradition (Yamano et al., 2009), whereas the intention here is to evaluate these in qualitative terms. The human development and capability approach (HDCA) throws more light and refreshing perspective on the processes involved in land acquisitions. A human development and capability approach yields a wider informational value including gender hence a nuanced analysis (Sen, 1999). Adopting the HDCA enables the evaluation of these large-scale acquisitions in terms of the procedural concerns of equity, efficiency, participation and sustainability (Deneulin \& Shahani, 2009) in relation to representation prior to and during land acquisitions. Such paradigm and procedural concerns enabled the evaluation of the modes of acquisition and gender differentiated impacts. Part of the reasons for the failure of some of these large land acquisitions to take off or endure is because they neglected these procedural concerns (International Land Coalition, 2011).

This paper provides an overview of recent developments in large-scale land acquisition and the effects of the promotion of the jatropha (jatropha curcas) cultivation on smallholder farmer's livelihood in northern Ghana. It is based on a study of the gendered impacts of large-scale land grabs in the Savannah and Northern Regions of Ghana. The focal points of study were two communities, Allipe in the Central Gonja District of the Savannah Region and Kpachaa in the Mion District of the Northern Region. Both towns are under the traditional jurisdictions of Kusawgu and Tijo respectively. This paper assesses the effects of large-scale land grabs. The assessment is done from the perspective of human development and capability which focuses on both the outcomes and procedural concerns.

The remainder of this paper is organised into six distinct sections. The first and second sections immediately following here discusses the theoretical underpinnings of land reforms and land grabs which were occasioned by neoliberal economic paradigms of the recent past. This is followed by a conceptualization of human development and capability approach. The third section explains the methodology adopted including brief discussions on the study area and data collection instruments. The findings, based on both primary and secondary data sources are presented in the fourth section while the fifth section discusses the 
findings within the concepts delineated in human development and capability approach. The final section comprises the conclusions and recommendations.

\section{Theoretical Underpinnings of Land Reforms and Land Grabs}

The current spate of land grabs were made easier by preceding neoliberal policies in the land sector. The basis of large land acquisitions for plantation agriculture has been described as an evolutionary and modernist agenda where poor, under developed nations with large arable lands and peasant way of life are expected to transit to capitalism (Moyo, 2008; Amanor, 2001). Akwensivie (2013) for instance has found a correlation between rise in foreign direct investment (FDI) and largescale land acquisition in Ghana over the last fourteen years. While this study by Akwensivie on the one hand indicates that the process of land grabbing pre-dated the recent global fuel and food crisis, another study by Amanor (2001) shows that the stage was set for the current land grabbing by previous neoliberal policies.

The neoliberal argument is that for an agrarian revolution to ensue countries are encouraged to pursue land reforms through the formal registration of lands or land titling (Razavi, 2014). Private ownership of land through land titling has been argued as the only way to unleash the potential of the peasant's locked capital in the form of unregistered land (de Soto, 2001). Formal registration is seen as a natural course for nations to take as all nations shall evolve towards the private ownership of land. The neoliberal underpinnings of private ownership of land is therefore identified with the evolutionary property rights school which argue that private land is the most efficient unit of agricultural production since owners are final claimants to profits and thus have higher incentives to put the land to the best use and improvement (Razavi, 2014; Amanor, 2001). The idea of formal registration of land or land titling has been discounted by Musembi (2007) who has argued that there are plural forms of legally recognizing ownership status of land in Africa. In addition, communitarian approach to land reforms challenges perspectives solely based on private ownership and economic efficiency and argues that land reform needs to meet the needs of rural communities and their socio-cultural value systems (Musembi, 2007; Amanor, 2001).

The belief in the evolutionary theory of land reforms, of moving from communal lands into privately held lands (land titling) has rather led to large-scale land acquisitions by corporate entities or individuals with large capital. It did not translate into the unleashing of capital into the hands of peasants as predicted by de Soto and others. An analysis of the land questions based on the evolutionary and institutional or communitarian approach and understanding of land reforms have however, tended to be focused on outcomes without paying sufficient attention 
to procedural concerns and on the gendered dimensions of land reforms and its implications.

Daley and Pallas (2014) have compiled an extensive literature linking land grabs to gendered experiences. For a start they noted that the World Bank's Gender in Agriculture Sourcebook did not address the gendered implications of land deals, except in a "Frequently Asked Questions" (FAQs). Among others, the FAQs raised issues with the growth of biofuels production on the resource constraints that might limit women's ability to work in biofuels production and the negative effects on family food security. Women's agricultural activities are displaced by related land deals, as well as impacts on "marginal lands" that contain important natural resources. The World Bank's FAQs raised further issues that women's time burdens would increase because they would walk farther to access new sources of water, firewood, and edible wild plants - journeys that would also make the women more vulnerable to gender-based violence (Daley \& Pallas 2014). Their land rights are routinely undermined through displacements, evictions, and encroachments (Nyari, 2008). In some instances poor women - who are often "women without men" to support them, are more likely to face violence and discrimination. Predatory male officials may not resort to sexual or violent abuse, but may view women land loss as less of a serious concern than men's land loss (Daley \& Pallas, 2014).

While definitions of what constitute large-scale land acquisition differ, there is concurrence on what land grab is. Cotula et al. (2009) posit that land grabbing occurs when there are large-scale land acquisitions that are above 1000 hectares. The Lands Commission of Ghana stipulates in its 2012 guidelines that lands above 400 hectares need to be referred to it before any acquisition is finalised. This implies that land sizes above 400 hectares are large-scale, but the guidelines are just that, non-binding and non-enforceable. It is however indicated by Graziano da Silva (2012) that not every large-scale acquisitions or lease of land should be considered as 'land grab'. He indicated that there are a number of benchmark considerations that should be analysed. The benchmarks are the needs, and rights, of the poor and vulnerable rural families, particularly smallholders, who are the main food producers in several countries. These benchmarks are more or less reiterated in the definition provided in the Tirana Declaration (International Land Coalition, 2011). In this declaration, land grabbing is conceptualised as land acquisitions or concessions that are characterised by one or more of the following:

(i) Violation of human rights, particularly the equal rights of women;

(ii) Not based on free, prior and informed consent of the affected land-users;

(iii) Not based on a thorough assessment, or are in disregard of social, economic and environmental impacts, including the way they are gendered; 
(iv) Not based on transparent contracts that specify clear and binding commitments about activities, employment and benefits sharing, and;

(v) Not based on effective democratic planning, independent oversight and meaningful participation.

Similar sentiments have been reiterated by some scholars who have argued that in a continent such as Africa where there is widespread poverty, vulnerability and human suffering, the approach to land policy and land rights ought to be humancentered and less driven by economic prescription than has been the case (Razavi, 2014; Amanor, 2001).

\section{Conceptualising Procedural Concerns in Land Grabs and Human Development and Capability Approach}

The UNDP over the past 29 years has tended to focus on redefining development and social interventions towards a human centred approach. Development can only be measured through the expansion of human capability or opportunity. The capability approach emphasises freedom and what people or groups of people can actually be able to do and to be (Sen, 1999; Alkire, 2002).

Bringing a human development and capability approach to a study of gendered experiences and impact on smallholder farmers' livelihood strategies in the face of land dispossession permits us to focus not only on the strategies or achievements of women but also to examine the extent to which they have freedom to achieve. At the core of the approach is the emphasis on freedom, particularly agency freedom, which emphasises the process aspect of inequality and achievement, which ensures that individuals have the ability to choose (Sen, 1999). The process aspects lead to a focus on how people get there (say participation in the negotiation process for land) and not only on the final outcomes. This enables us to tease out the effects of gender difference better since issues such as participation are relevant in a context where patriarchy is dominant. Colclough (2008) has argued that the most marked gender inequalities are found in countries and regions where women's roles are constrained by patrilineal principles of inheritance and descent, by early marriage, by family resources being controlled by the senior male household member and sometimes by traditional restrictions preventing women participating in the public sphere (Colclough, 2008).

The human development and capability approach combines a focus on outcomes with a focus on processes. Four key principles and procedural concerns have been used repeatedly in applying the human development and capability approach. These are: equity, efficiency, participation and sustainability (Denuelin \& Shahani, 2009; 
Alkire, 2002). Other principles such as responsibility or respect for human rights also matter. But the emphasis is on these four because they are often used and are also in tandem with the Tirana Declaration mentioned earlier (International Land Coalition, 2011). These procedural concerns must be seen as multidimensional, dynamic and interrelated and not as isolated indices.

Equity draws on the concept of justice, impartiality and fairness and incorporates a consideration for distributive justice between groups. In human development, equity draws attention to those who have unequal opportunities due to various disadvantages and may require preferential treatment or affirmative action (Denuelin \& Shahani, 2009; Robeyns, 2003). The objective of land policies and legislation was to promote investment in land, raise agricultural productivity and enable sustainable land use but these often had negative consequences for the land rights of some social groups (Daley \& Pallas, 2014). For instance, land titling and registration programmes often entailed loss of the land use rights of women and pastoralists and new vulnerable groups requiring the attention of policy makers (Cotula et al., 2004).

Efficiency refers to the optimal use of existing resources (Yamano et al., 2009). From a human development perspective, efficiency is defined as the least cost method of reaching goals through the optimal use of human, material, environmental and institutional resources to expand capabilities for individuals and communities (Denuelin \& Shahani, 2009). It is necessary to demonstrate that the chosen intervention offers the highest impact in terms of people's opportunities. This directly answers the question as to whether the new jobs and economic paradigms offered better opportunities for wellbeing than peasant agriculture.

Participation and empowerment is about the freedom to make decisions in matters that affect their lives, the freedom to hold others accountable for their promises and the freedom to influence development in their communities (Alkire, 2002). This principle implies that people need to be involved at every stage, not merely as beneficiaries but as agents who are able to pursue and realize goals that they value and have reason to value (Denuelin \& Shahani, 2009). The key question this principle enables us to pursue is whether women were involved during the negotiation processes for land acquisition or not and the roles they played when promises offered by these interests did not materialize. This incidentally is the second principle found in the Tirana Declaration which seeks to ensure that land acquisitions are based on free, prior and informed consent of the affected landusers. Finally, sustainability refers to advancing human development such that outcomes progress in all spheres - social, political and financial - endures over time (Denuelin \& Shahani 2009). Environmental sustainability implies 
achieving developmental results without jeopardizing the natural resource base and biodiversity of the region and without affecting the resource base for future generations. Social sustainability refers to the way in which social groups and other institutions are involved and support development initiatives over time, and avoid disruptive and destructive elements. The procedural concerns of sustainability enable an analysis based on the short to long term impacts of large-scale land acquisition.

\section{METHODOLOGY}

\section{Study Area}

Northern Ghana is made up of five administrative regions which are Northern, Savannah, North East, Upper East and Upper West Regions. Northern Ghana is clearly separated from southern Ghana by various tributaries of River Volta and covers a land area of approximately $97,702 \mathrm{~km} 2(41 \%)$ of Ghana's total land mass (Boafo et al., 2015). The area is characterized by semi-arid climatic and physical conditions, dominated by the Guinea Savannah grassland. It has two marked seasons namely, the wet and dry seasons. The South-Western Monsoon winds from the Atlantic Ocean bring rains mostly between April and August, whilst the NorthEastern Trade winds from the Sahara Desert bring the long dry season between November and March. The mean annual rainfall varies between $840 \mathrm{~mm}$ and $1400 \mathrm{~mm}$. Monthly temperatures vary from $36^{\circ} \mathrm{C}$ in March to about $27^{\circ} \mathrm{C}$ in August (Nikoi, 2010). In the dry season, the dry and dusty harmattan winds from the Sahara Desert are very intense (Amikuzuno \& Donkoh, 2012). The long dry spell promotes the occurrence of bushfires, exposing the soils to erosion by wind and rendering it too impoverished to support plant growth (Yiran et al., 2012). Unstable climatic conditions during planting season affect crop yields. Food production systems and agriculture generally is rain fed despite the short rainy season. With a largely rural population and high levels of poverty, northern Ghana is very susceptible to variations in climate (Boafo et al., 2015; Bhaskar et al., 2015). The main crops cultivated in this vegetation belt include rice, millet, maize, guinea corn, sorghum and yam. Commonly found trees are the shea, dawadawa, kapok and baobab. The trees have long tap and fibrous root systems that penetrate the soil to access water. Seasonal migration particularly among young women occurs from most northern communities to urban centres such as Accra and Kumasi in the south. The young women undertake work as porters in the market centres of these cities (Apusigah, 2009). 
Northern Ghana has a unique land tenure practice. Chiefs tend to hold lands in trust for the community and such privilege has become de facto ownership and control of land (Gasu and Agbley, 2015). Nevertheless chieftaincy as an institution was a recent phenomenon in Ghana. Some parts of northern Ghana, especially the Upper West Region and some parts of the Upper East Region were ruled and controlled by the 'Tindaana' or 'earth priest' (Apusigah, 2009). Chiefs were imposed on communities by colonial authorities especially in northern Ghana where there were no chiefs at the time. The Tindana ministering as the earth priest was the custodian of the community land (Mason, 1993). In northern Ghana the allodial rights rested in the community; while the usufructuary rights are exercised by the patrilineal lineages (Asenso-Okyere, 1993). Land in this respect could neither be appropriated by the tindana nor lineage heads as their individual private property. But the evidence is mounting that chiefs continually allocate large-scale lands to both local and foreign mercantile interests.

For the purpose of this study, two rural communities were selected for a focused in-depth study. These communities were Allipe which falls under the traditional jurisdiction of Kusawgu in Savannah Region and Kpachaa which is under the traditional jurisdiction of Tijo in Northern Region (Figure 1). These two communities were selected based on the alarm raised by a number of NGOs operating in these communities who saw at first hand the clearing of large contiguous lands (Nyari, 2008; Action Aid, 2014). 


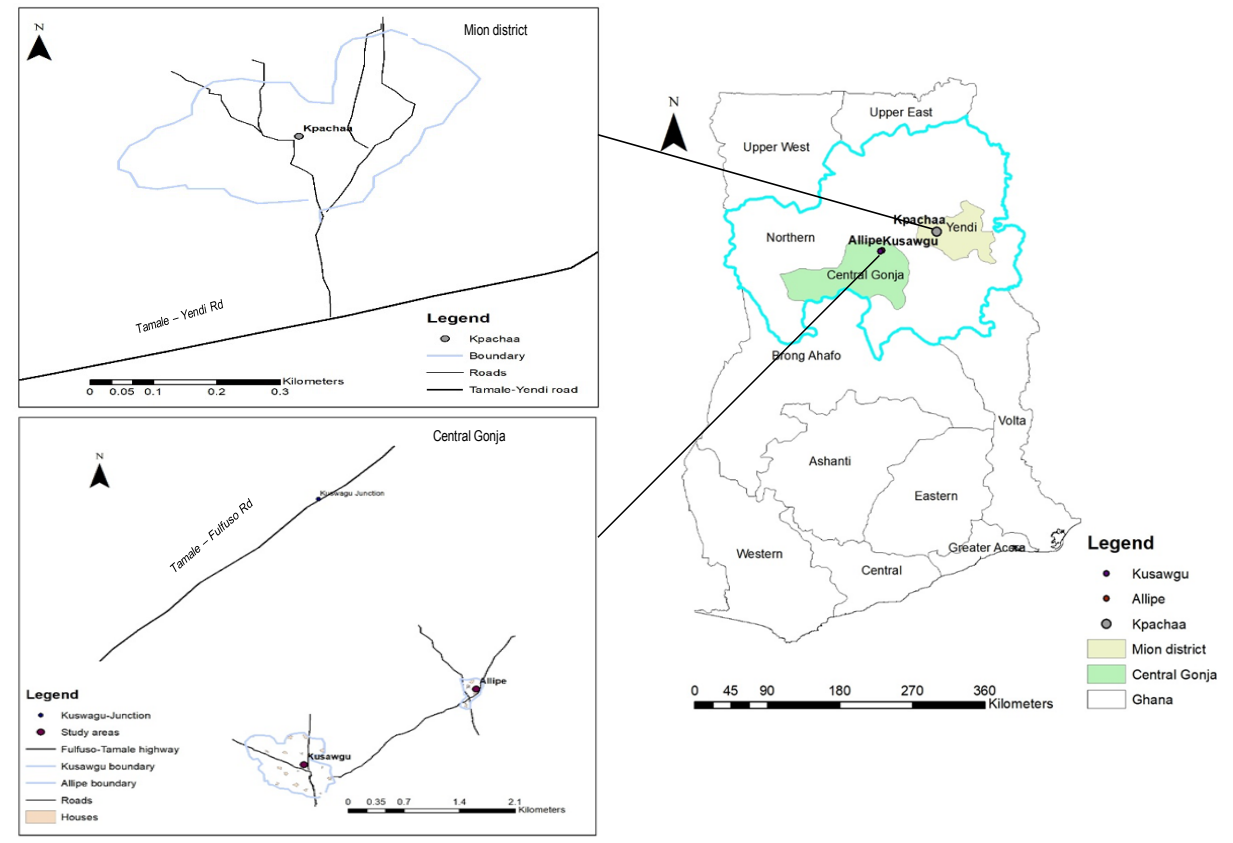

Figure 1: Map showing case study communities in relation to the study area.

\section{Methods}

\section{Data Collection Processes and Techniques}

The study adopted purely qualitative in-depth study research approach which employed various research techniques (Neuman, 2012). The data collection methods adopted comprises: focus group discussions and interviews with key informants and community members, reconnaissance survey and observations (Robson, 2006). These methods were carried out in May 2015 and June-July 2016 to generate primary data while the secondary data on the incidence of large-scale land deals was extracted from records at the Office of the Administrator of Stool Lands, Accra. The researcher was aided by a field assistant who offered translation services translating discussions from the English language into Dagbanli and Gonja language and vice-versa.The study further focused on the activities of one of the largest land acquirers; a Norwegian owned Biofuel Africa Ltd (now Solar Harvest Ltd). The company acquired lands in the two communities which are the subject of the study: Kpachaa and Alipe. Data gathering was categorised into two major phases: In May 2015, the first phase also known as community entry was employed to negotiate access and entry with key informants and gate keepers involved with the two projects: the Assemblymen, sub Chiefs, Regional Lands Officer, staff from the Office of Administrator of Stools Lands. The second phase which occurred 
between June and July 2016 entailed the administering of interview questions, and the conduct of Focus Group Discussions (FGD).

\section{Reconnaissance Survey and Observation}

A reconnaissance survey which entailed a walk through the communities, observing general community ambience and activities of daily living (cooking, washing, carpentry, the drying of ground nuts,etc.) was carried out (Boafo et al., 2015; Robson, 2006). The research team visited the sites acquired by Biofuel Africa and jatropha plantations. After the observation of the above mentioned facilities, field notes and photographs were taken to reflect what was detected as well as findings for the report.

\section{Focus Group Discussions}

The FGDs were employed to engage with community members through face to face discussion in other to understand perceptions and knowledge of the processes and impacts of the activities of Biofuel Africa within the study area. FGD guide was the data collection tool used during the engagement with the women respondents. The women were grouped into: (i) young women aged 40 years and below and (ii) older women of 41 years of age and above. A total of four focus group discussions were held within the data collection period.

\section{Interviews}

The interview was targeted at the men. A total of twenty (20) men were interviewed; with ten men in each community. Interviews were conducted both at the residence of the respondents and as well as on the field (including work places). All interviews and focus group discussions were tape recorded and later transcribed. The interviews and focus group discussions with participants in this study centered on (a) the antecedents of land grabs in their community and levels of participation by all categories of persons both male and female, (b) the operational activities of BioFuel Africa, (c) services rendered to the community by the company, and (d) current subsistence adaptations and livelihood situation of the two communities.

\section{Data Analysis}

Data analysis entailed the categorization of the information obtained into key themes, drawing up a case study scenario and conducting a reflexive exercise to derive meanings and interpretations of the data (Neuman, 2012; Robson, 2006). The key themes derived from the study are the impact of land grabbing on livelihood, equity, efficiency, sustainability and participation. These themes together focused 
on the overall impact of the large-scale land acquisition in the two communities from a human development and capability perspective.

\section{RESULTS}

\section{The Nature and Extent of Land Grabs in Northern Ghana}

The recent spate of land appropriations has been dubbed 'land grabbing' in northern Ghana (Action Aid, 2014) due to the apparent avarice and subterfuge that drives the acquisition. Large land acquisition by foreign mercantilist interests have impinged negatively on local community entitlements and accessibility (Tsikata \& Yaro, 2011). In an interview with an official at the Regional Lands Commission in Tamale, it was revealed that, chiefs of various communities in the Northern Sectors of Ghana including the study areas continually allocate large scale lands, to both local and foreign mercantile interests, even when they do not possess the requisite skills to fully negotiate and release such lands. Summarising from both primary and secondary data gathered so far, the results show a rising tide of poorly negotiated lands for allotments, community tensions and conflict due to communities losing allodial and usufructuary rights. The projects which are the focus of the study, hanged in the balance without providing the needed jobs promised. The Office of the Administrator of Stool Lands, Accra, has records of the extent of large-scale land acquisitions in the Northern Regions of Ghana now Northern and Savannah Regions. Since the year 2007, a total of 154,812 acres (63,06o hectares) have been purchased or allotted to both foreign and local entrepreneurs in various land deals in the Savannah and Northern Regions of Ghana as indicated in Table 1.

\section{Table 1: Land grabs in the Savannah and Northern Regions of Ghana}

\begin{tabular}{|l|l|l|}
\hline Location & $\begin{array}{l}\text { Details of the Allocations (Size, } \\
\text { Term, Acquirer, Use) }\end{array}$ & Remarks \\
\hline $\begin{array}{l}\text { East and Central Gonja } \\
\text { Districts }\end{array}$ & $\begin{array}{l}\text { 68,ooo acres } \\
\text { 40-year lease } \\
\text { Wholly owned local enterprise } \\
\text { Commercial Agric\& Forestry }\end{array}$ & $\begin{array}{l}\text { No show. Project stalled by } \\
\text { local interest groups and } \\
\text { Lands Commission }\end{array}$ \\
\hline $\begin{array}{l}\text { Mion (formerly part of } \\
\text { Yendi District) }\end{array}$ & $\begin{array}{l}42,705 \text { acres } \\
50-y e a r \text { lease } \\
\text { Wholly owned local enterprise } \\
\text { Jatropha }\end{array}$ & Project abandoned \\
\hline
\end{tabular}




\begin{tabular}{|l|l|l|}
\hline Central Gonja District & $\begin{array}{l}\text { 27,000 acres } \\
85-\text {-year lease } \\
\text { Foreign Direct Investment } \\
\text { Plantation }\end{array}$ & \\
\hline $\begin{array}{l}\text { Buipe, Central Gonja } \\
\text { District }\end{array}$ & $\begin{array}{l}\text { 8,247 acres } \\
10-\text { year lease } \\
\text { Foreign Direct Investment } \\
\text { Agriculture }\end{array}$ & $\begin{array}{l}\text { Yams, Maize cultivated on } \\
\text { 3,00o acres }\end{array}$ \\
\hline Cheogu, Yendi District & $\begin{array}{l}\text { 8,86o hectares } \\
\text { 45-year lease } \\
\text { Foreign Direct Investment } \\
\text { Commercial Agric. }\end{array}$ & Shea Plantation commenced \\
\hline
\end{tabular}

Source: Stylised Regional Survey by Author (2016).

Data: Office of the Administrator of Stool Lands (2014)

\section{A Case of Land Grab in Northern Ghana}

Biofuel Africa Limited (BAL) is an independent company registered in Ghana and owned by Solar Harvest AS (Norway). The company is focused on upstream biofuel production from jatropha. Its business objective is on the premise that jatropha is possibly the most sustainable feedstock for large-scale biofuel production. Its business model hinges on leasing large tracts of managed land in Africa, primarily Ghana. The company asserts that it pursues a Food First policy by providing local farmers with mechanical farming assistance to maintain and extend their farms as well as produce food products on most suitable land. It has therefore contracted for lease of 154,778 hectares (382,464 acres) of own managed land in Ghana. It has surveyed 55,161 hectares (136,306 acres) and has obtained Environmental Protection Agency permit which is required for farms beyond 40 hectares. Out of total land surveyed, BAL had successfully acquired land title from the Lands Commission for 10,696.32 hectares (26,431.18 acres) as of April 2009 while extracting its first juvenile oil of 50 barrels in 2008. BAL expected to produce 35,000 metric ton (MT) per annum jatropha oil when trees were fully matured in 2013 (equivalent to 652 barrel per day oil production). BAL cleared large tracts of land in Allipe and was stopped. In Kpachaa, after the successful clearing of land, jatropha was planted. The company ceased operations in 2011 and could not produce any commercial quantity of biofuel. It maintains few key staff (security and Ghanaian representative) as well as abandoned farm machinery. The jatropha plants are abandoned and the fields over grown with weeds. Meanwhile community members are unable to claim the lands back or reuse them. 
In an interview with the company`s representative with some of the emerging issues confirmed during the focus group discussion, the company had promised to provide job opportunities (approx. 1 person per 10-15 hectares for mechanised farming), water dams, ploughing new land for indigenous farmers, maize grinding mill, a health post, courses in tractor operations, tree planting of moringa and shea nut trees. The research also revealed that, BAL promised it future plans to include undertaking beehives and honey production, fire briquettes production, electrical power generation as well as construction of schools. The research finding however identified that, these BAL plans were not stated in a binding agreements with the communities and one could not tell the ownership structure of these proposed projects and schemes. It was also detected that, during the operations of the plantations in Kpachaa, ex-workers of BAL reported that they were paid the equivalent of 35 USD a month, an amount which is substantial compared to the reported annual returns of USD 250 the peasants earned from farming. The research by calculation further revealed that, the monthly wages were available all year round making most households food insecure during the critical months of the dry season due to the opportunity cost of working on the commercial plantations instead of cultivating the land for food crops. It was also revealed that, BAL abandoned the Allipe project and closed down the Kpachaa operations but failed to replant the field with sheanut trees which takes up to 14 years to mature after planting. Members of Kpachaa community reminisced of the good recent past when jatropha cultivation was in full operation. According to a young male respondent:

We use to live in a sleepy village on the Tamale - Yendi road and it became buoyant with commercial activity because of the project (pointing to jatropha farms). Migrants from near and distant villages came to work in our town.

Another respondent commented: "These migrant workers from the big towns brought in 'civilization' to our way of life".

The activities of the business operation of BAL therefore brought about changes to the communities and made impacts on their lives. It however failed to consult widely in its land negotiations with local chiefs. Community members, including low ranking men and all categories of women (high and low ranking) were not consulted.

\section{Effects of Land Grabs on Peasant Livelihoods}

Land dispossession has impacted men and women differently. For men, it has been the loss of commons for grazing cattle as well as hunting of game (Daley \& 
Pallas 2014; Tsikata \& Yaro, 2011). Meanwhile the promised jobs on the Jatropha plantations did not materialize in a sustainable way. Having lost their farms to these large-scale commercial enterprises, the men of Allipe and Kpachaa also suffered the double jeopardy of losing their jobs. This is because the project failed to take-off (Allipe/Kusawgu) or was abandoned (Kpachaa). The consequences for food security in these communities are enormous since these workers would not have cultivated any food crops for the lean season. A young man in Kpachaa commented: “I couldn't farm any maize or groundnut since I don't have any land...I enjoyed working for the company because they paid me a monthly salary and I didn't need to farm always. It was better."

But women are the hardest hit when communities lose their lands to land grabs. The recent World Bank report on land grabs in Africa (2014) estimate that $70 \%$ of smallholder farmers are women. This means that the majority of people afflicted by land grabs are women and has snowballing effects on household food security and wellbeing. Interviewees complained that they have to trek long distances to new farms which took away time meant to attend important family business. Women reported that they cooked for the men who tilled the field. This brought in extra income. However they were not directly employed on the plantations (Cotula et. al., 2004).

The vast uncultivated lands of northern Ghana provide another major source of livelihoods especially for rural people. The savannah is the source of such economic trees like the shea tree (Vitellaria paradoxa) and locust bean tree (Parkia biglobosa) known locally as dawadawa. The products from the wild are normally seen as women's 'crop' because they are gathered by women and children. The shea fruit has an oil bearing nut that is processed by women. The oil is used as edible oil and for the production of cosmetic goods. The locust bean seeds are often processed into a nutritious seasoning or condiment. Foods extracted from tree crops are rich in vitamins, minerals and proteins. For instance the iron content of the African locust bean is higher than found in chicken meat (Bhaskar et al., 2015). Although these trees are not cultivated but rather grow in the wild, they are important sources of income for the people too (Apusigah, 2009). The loss of biodiversity through the outright clearing of all trees including sheanut trees and the failure of the local elite to have included re-entry clauses in land sales have exacerbated the community loss. While shea nut sales are booming in nearby communities, there was no single nut being picked or dried in Allipe and Kpachaa. The focus group discussions reveled that Kpachaa has failed to produce shea butter or oil since 2007 when the land was acquired and cleared. 
The effects of land losses to communities go far deeper and are intertwined with the very fabric of social and communal organisations. From the interviews conducted, both study communities no longer look forward to any festivals or ceremonies associated with farming. For instance the availability of food serves useful purposes other than only mitigating hunger, itself important nonetheless (Sen, 1999). The peasant way of life, organised around the farming seasons and harvests lead to important rites such as festivals. Such occasions enabled the community to take stock and look forward to the New Year. The onset of rains, communal planting and harvesting mark various stages and important rites and rituals in the life of a community, further enhancing its sense of identity and communal belonging. The food harvested itself marks the time for celebration and merry-making, a time to make amends and forgiveness and a commitment to live peaceably with one another. It is the time wives receive gifts from husbands particularly wax print textiles that serve many useful purposes.

The two distinct climatic seasons of northern Ghana bring to the fore the usefulness and critical need of the commons. It has a single and relatively short raining season for farming and its long dry season from November to April where no food is grown; it is therefore necessary for families to have alternative sources of income. It is during the long dry season that the important collection of shea and locust bean seeds takes place. The processing of these products are women's communal affairs where the tedious and long processing of shea is shared. The communal processing of shea further enhances group solidarity and bonding but also crucially earning an income in otherwise hostile season. The women at the focus group discussions pointed to the equivalent of a 5 kilometer radius beyond which they wouldn't travel to pick nuts. They gave reasons why they couldn't travel farther from the homestead: “...we don't have resources such as motorbikes to travel far from here to the farm".

An elderly woman mentioned: "We have to return to the house sooner to prepare evening meals, go to the market or process shea nuts into butter".

They complained the distance has made shea processing tedious and has slowly led to the decline of the shea industry in the villages. The farther out women go to collect these products, the less time available to communally support each other during shea processing. The safety and security risks involved deter people from wandering farther away from the homestead to pick sheanuts. 


\section{DISCUSSION}

\section{The Human Development and Capability Approach}

The social identity of rural people emerges from the communal ownership of land in which the allodial rights is vested while their economic identity emerges from the fact that they have unfettered usufructuary rights to the land and commons (Boamah, 2014). Indeed the possession or access to and use of land define one's citizenship since what a community possess is indivisibly linked to who they are (Lund, 2011). The acquisition of huge tracts of communal lands tends to have differential consequences for all categories of users. Poor rural households in low-income countries seek to meet their basic needs for survival, minimise risk in terms of security and generate a sufficient surplus to invest in their future (accumulation) through a variety of activities and using a variety of tangible and intangible resources (Kabeer \& Van Anh, 2002). For all categories of land users, such large-scale land grabs dispossess the community of its allodial and usufructuary rights. Smallholder farmers can no longer farm on these lands, harvest its fruits nor hunts its game (Boamah, 2014; Nyari, 2008; Cotula et al., 2004). Smallholder farmers therefore lose livelihood resources such as claims and entitlements to such lands as well as the benefits that the commons may offer. They are therefore reassigned to new farms further away from the community settlement as well as often a reduction in land size for farming (Tsikata \& Yaro, 2011).

\section{Equity}

The nature of land holding is such that although community 'owned' the lands in the custody of chiefs, chiefs appropriate monies paid for lands with nothing or paltry compensations paid (Gasu \& Agbley, 2015). Once Biofuel Africa dealt with the Tijo Naa and Kusawguwura, it felt no need to deal or compensate the community which suffered the immediate impact (Kpachaa and Allipe respectively). The custodian of the land at Kpachaa is the divisional skin of Tijo (a community about 40 kilometers away). The paramount chief of Tijo (Tijo-Naa) is superior to and does not account to the local chief of Kpachaa. Respondents made it clear that their community, Kpachaa, has no say in land deals from which it has always farmed. Such local arrangements were well understood and therefore not contested. Boamah, (2014) has argued that land tenure agreements are often executed at the behest of chiefs who allocate and dispose of land in a patrimonial manner. In Alipe and Kpachaa, compensations were not expected and therefore not demanded, hence were not paid. Farming communities such as Allipe and Kpachaa therefore suffered the most from the dispossession and clearing of lands they depended on over a long period of time. The promise of jobs was enough and as the women pointed out 
'it was no use to contest the powerful Tijo-Naa'. Equity from a human development perspective was therefore lacking in many respects particularly when land owners were consulted and compensated but land users were not. This depicts partiality and a lack of fairness.

\section{Efficiency}

In order for a cost effective operation in terms of haulage costs and ease of accessibility, the jatropha plantation is close to the community and across the highway. The experience from southern Ghana and during the colonial era is that large-scale plantation projects like palm and rubber plantations are cited far from settlements (Amanor, 2001). The BAL site is located along the Yendi-Tamale highway which is prime land. This section happens to be where the community farmed and picked sheanuts. According to some of the male respondents, women are allowed to farm closer to the community for safety and security reasons. This implied that the very site of BioFuel Africa's project use to be 'women's farm land'. The site of the project meant that women's household daily activities were impacted negatively sine they have to travel farther than they used to (Daley \& Pallas, 2014). Another dimension of cost cutting and ensuring efficient farming is the total removal of all trees and stumps to ensure a fully mechanized operation. This is alien to the kind of agriculture practiced by smallholder farmers. Smallholder farmers adopt an agroforestry method of farming and therefore incorporate cultivation within the tree population of the land. The total removal of trees for mechanization and efficient productions adopted by BAL destroyed all the trees within the farming fields. Agro forestry enhances adaptation to climate change calamities as well providing essential ecological services such as preserving watersheds (Bhaskar et al., 2015). This in turn, is essential for crop and livestock production.

Efficiency in terms of comparing wage labour to farm earnings is a poor way to evaluate impact due to the forgone opportunity costs such as not being able to cultivate own food. Also a simple assumption that wages were higher compared with farm sales by the peasants failed to incorporate the savings made from nonpurchase of foods. However Kpachaa community members reported that the higher incomes earned from wage employment led to surpluses that financed other nonfood purchases such as education and a general contentment of wellbeing. Similar arguments made by the World Bank FAQs and discounted by Daley \& Pallas (2011) showed an apparent disconnection of the incidence of food insecurity being experienced in the community, from the activities of the plantation operator. The community therefore wished for resumption in operation of the plantation. There was excitement in the voice and eyes lit when members of Kpachaa discussed the project. The emergence of wage employment, sudden population swell and the hive 
of commercial activities such as cooked food vending by the women, all contributed to the strong desire for a resumption of the jatropha cultivation. Just as quickly the capitalist culture of dependency on waged labour emerged, so did it fade when the company funds dried up. Kusawgu/Allipe did not taste it at all although it witnessed its destructive forces at first sight and wanted none of it.

\section{Participation and Empowerment}

The respondents pointed out unanimously the land negotiation in Kpachaa and Alipe (carried out by Tijo-Naa and Kusawguwuraa) did not involve women at all and only included elite men (the land lords Tijo-Naa and Kusawguwuraa and their elders).This is due in part to the fact that such communities only exercised user rights and were not custodians or owners of such lands (Boamah, 2014). Distant owners, often a higher chiefly office or paramountcies living further away from the project site are the true custodians of the land. Respondents revealed that these chiefs are not answerable to people who they had extended some benefaction to use 'their' lands. In Allipe, the raising of the alarm bells by civil society group RAINS led to a community gathering in Kusawgu. Consultations therefore only started after the land had been sold and work commenced. The full participation of all concerned in the public forum was empowering to the extent that women questioned the failure of Biofuel Africa to make binding commitments of promises made since their source of livelihoods like shea nut trees were destroyed.

However, in Kpachaa, a woman of high rank commented that the Tijo-Naa, custodian of the land had banned their local chief from further making comments to the media and researchers on the BAL project. She further intimated that the community did not want trouble with the Tijo-Naa. She feels that researchers have not carried across the positive value obtained from the huge investments. Daley (2011) has argued that although women are not a homogenous group, and their experience of land deals differs according to their socioeconomic status, women are likely to be affected both differently as well as negatively affected than men because they are generally vulnerable as a group. This vulnerability manifests in the dimensions of access to productive resources, relative income poverty, physical vulnerability, and participation in decision making (Daley, 2011).

The responses to direct questions from adult males and females in Kpachaa unlike Allipe, have been one of praise for the project. References to the benefits include the provision of two boreholes, a clinic and a corn mill in the community. Previously the community had to travel a distance of about 8 kilometers in the valley to fetch water and in the long dry season water scarcity was a major issue. Respondents reported that men had to dig manually to reach the water table and women 
spent all day to obtain a bucketful of water. The constructions of the boreholes therefore have been highly commendable because it shortened time spent for water. However, responses from younger citizens of the town, have been more modest and recognize the negative impact of the projects. The lack of a shea nut industry in the community compared with neighboring villages was raised by the youth. A young man, in his early thirties wondered "why are other communities doing so well in the shea trade and not ours". The women differed in their responses to similar questions. The elderly women attributed the lack of the crop to population increases. A young woman in a somber tone pointed out that shea use to be collected 'over there', pointing her index finger towards the cleared fields of the jatropha plantations. The clinic stopped functioning when the company suspended activities. The corn-mill, a diesel operated equipment is no longer patronized. Respondents opined that a newly installed corn mill in the town of Jemile (6 kilometers away) is powered by the national electricity grid and was therefore more efficient.

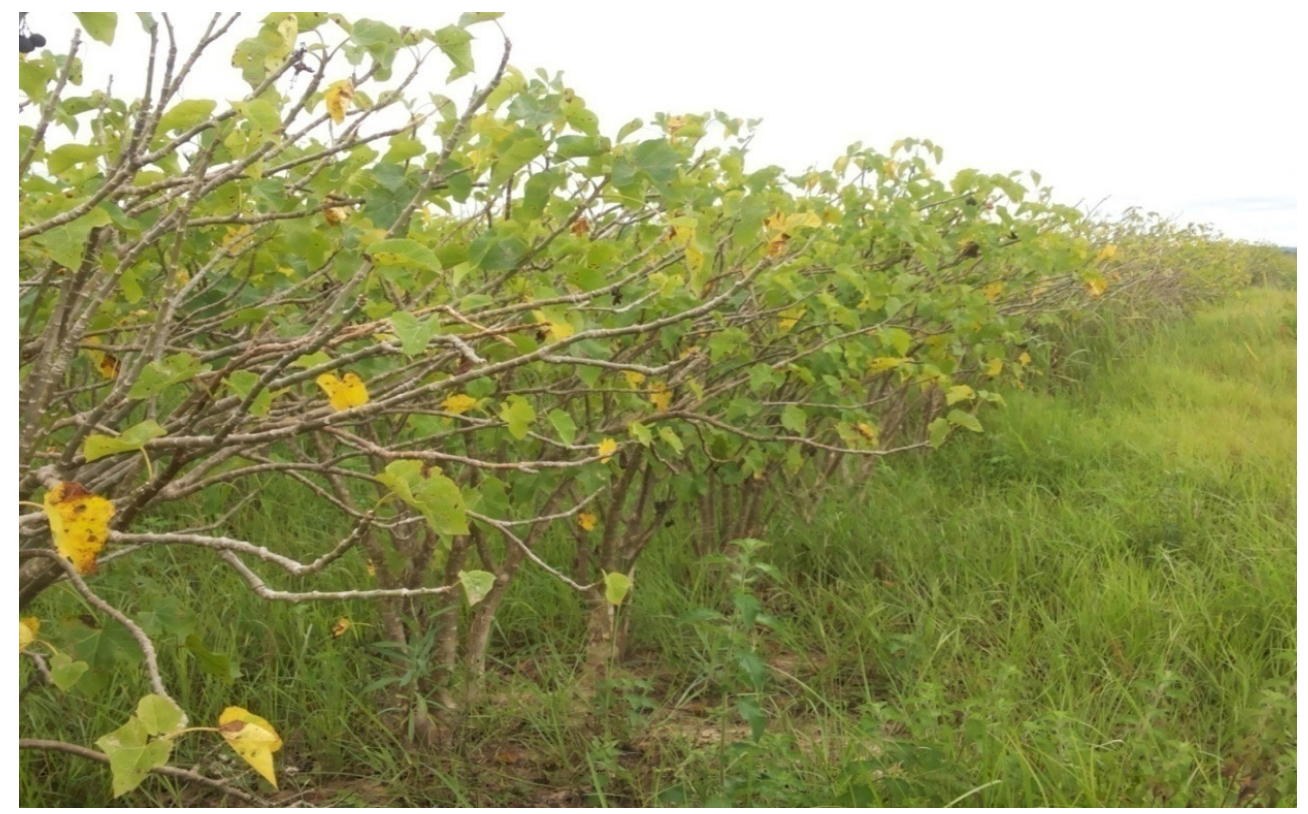

Figure 2: Jatropha plantations at Kpachaa. Source: Author, 2015

\section{Sustainability}

The inability of BioFuel to continue jatropha cultivation and production of biofuel in commercial quantities showed that the project was environmentally, socially and economically unsustainable. Environmentally, it had cleared large tracts of land and abandoned them. Such an activity degrades the land (Bhaskar et al., 2015; Yiran et al., 2012). Socially the activity of BAL brought about changes to the social 
and cultural organisation of the community (Razavi, 2014). The transformation of Kpachaa from a quiet and sleepy village to a vibrant polity, and then the sudden reversal to a quite settlement created a void. Kpachaa is finding it difficult to adjust to the void. Economically, the jobs promised are no longer to be found. Tsikata \& Yaro (2011) whose argument that plantations tend to employ mostly men holds true in Kpachaa, the jobs were however not sustained. Further, the community suffered the double jeopardy of losing their jobs while not being able to farm on the cleared sites. The lands have become private property and no re-entry clauses were inserted in the lease agreements (Nyari, 2008). The disruptive social consequences of BAL's activities did not in any way contribute to the country's export (Razavi, 2014; Tsikata \& Yaro 2011). Razavi (2014) has further pointed out that the foreign direct investment made by organizations such as BAL and encouraged by international financial institutions do not provide stable and sustainable basis for growth.

Many women's cooperatives and support groups across the northern savannah of Ghana are built around the processing of sheanuts and charcoal making (Apusigah, 2009). The crops are major ingredients in food preparation and for cosmetic purposes. Since the sheanuts and locust beans no longer existed, the useful skills in processing are gradually being lost. When young women were asked about their ability to process sheanuts, most of them said they couldn't. Meanwhile it will take up to fourteen years for new shea plants to fruit if they are replanted and the community is able to get back its land. According to the company representative, there is intention to restart the project when funds are available and therefore the company is not likely to grant such permit for re-entry. Meanwhile the community of Kpachaa desires strongly a return to the recent past of full operations of jatropha cultivation. It does not entertain the possibility of re-entry and usage of the lands. Allipe rues the loss of economic trees and does not look forward to the company returning.

\section{CONCLUSION}

This paper has discussed the effects of large-scale land grabs on smallholder farmers. Neoliberal economic policies which focused on the private ownership of lands through land titling has rather led to large-scale land grabs rather than unleashing the capital of the peasants. Neoliberal economic argument for land grabs have focused on income generation and growth through exports. It had focused less on impact on people. People-centred development paradigms such as human development and capability approach have enabled us to focus on how these large-scale lands grabs impact smallholder farmers. This is achieved through procedural concerns such as equity, participation, sustainability and efficiency. 
On the whole, the nature of capitalist interventions in terms of maximization of profit and ensuring a least cost approach to investments in the name of ensuring efficiency is plausible in the short term. However the long run effects of total destruction of trees for full mechanization to be possible, undermines the capability of smallholder farmers to harvest fruits and farm closer to their settlements. In addition, the grabbing of lands so close to the community for ease of access does not necessarily expand people's opportunities since they would have to travel further into the hinterland to produce essential food. The practice in southern Ghana has been for such large-scale investments to be sited farther from the community and the investor providing means of transport for its workers. It also ensures the safety and security of the investment when sited farther afield (Amanor, 2001).

Drawing lessons so far, it could be concluded that women and community members generally did not feel empowered to question or hold powerful local elites and global forces accountable without the active support of civil society groups. The vulnerability of women and community members make worse their empowerment and participation levels in land deals. The question remains whether if women were to participate in land deals, does that empower them and would it have prevented all the disastrous consequences of much promised but poorly implemented and short lived biofuel projects? The answer may be unknown but we may draw on an Akan proverb that literally translates: "Wisdom does not lie in the head of one person". Broader consultations while not guaranteed, may have unearthed the many issues that were raised by the women during the focus group discussions. The women in Allipe were more vociferous in their objection to the project due to the clearing of the shea and dawadawa trees. Whereas the opportunities the plantation brings to communities such as Kpachaa and Allipe may expand in the short term, real opportunities may actually diminish in the long term along equity and sustainability lines. Efficiency through a narrow view of least cost and maximization of profit favours the investor again in the short term but have negative consequences for the environment and the peasant way of life in the long term. Participatory and empowerment processes although practiced in some respects, came rather too late in Kusawgu/Allipe and not in Tijo/Kpachaa because of the collusion with local elites.

From a human development perspective, the land grabs in northern Ghana have failed to incorporate procedural concerns based on equity, efficiency, participation and sustainability. BioFuel Africa Limited's acquisition therefore fits the Tirana Declaration's conceptualization of land grabs as violating human rights, including the equal rights of women; not based on free, prior and informed consent of the affected land-users; are in disregard of social, economic and environmental impacts, including the way they are gendered. The land grabs were not based on transparent 
contracts that specify clear and binding commitments about activities, employment and benefits sharing, and not based on effective democratic planning, independent oversight and meaningful participation of all stakeholders including land users. It is recommended that future land grabs if permitted should be sighted further from the community. Communities must be supported by state agencies such as the Office of the Administrator of Stool Lands, the Lands Commission and civil society groups to ensure land negotiations are embedded with re-entry clauses, binding contractual agreements and sustainable land use systems.

\section{References}

Action Aid, (2014). Stop land grabbing in northern Ghana. Acessed http://www. northernghana.com/?n=2418. July 122014.

Akwensivie, G.A. (2013). Land grabbing in Ghana - Myth or Reality? 13th Africa Real Estate (AfRES), Development Conference, held at Lemigo Hotel, Kigali Rwanda from 23rd to 26th October 2013.

Alkire, S. (2002). Valuing freedoms: Sen's capability approach and poverty reduction. Oxford: Oxford University Press.

Alkire, S. (2005). Capability and functionings: Definition and justification. Human Development and Capability Association Briefing Note. New York.

Amanor, K.S. (2001). Land, labour and the family in southern Ghana: A critique of land policy under neoliberalism. Research Report No 116, Uppsala: Nordiska Afrikainstitutet.

Amikuzuno, J. and Donkoh, S.A. (2012).Climate variability and yields of major staple food crops in northern Ghana, African Crop Science Journal, 20 (2), pp. 349-36o.

Apusigah, A. (2009). The gendered politics of farm household production and the shaping of women's livelihoods in northern Ghana. Cape Town: Feminist Africa.

Asenso-Okyere, W. K., (1993).Communal property resources in Ghana: policies and prospects. Discussion Paper No. 27. Institute of Statistical Social and Economic Research, Legon: University of Ghana.

Bhaskar, V., Wildburger C. and Mansourian S. (2015). Forests, trees and landscapes for food security and nutrition: A global assessment report. Available at www.iufro. org/fileadmin/material/publications/iufro-series/ws33/ws33.pdf. Accessed on 14th April, 2019.

Boafo, Y.A., Saito, O., Kato, S., Kaiyama, C., Takeuchi K. and Nakahara M. (2015). The role of Traditional ecological knowledge in ecosystem services management: 
the case of four rural communities in Northern Ghana. International Journal of Biodiversity Science, Ecosystem Services \& Management. 12(1-2), pp. 24-38.

Boamah, F. (2014). How and why chiefs formalise land use in recent times: the politics of land dispossession through biofuels investments in Ghana. Rev. Afr. Polit. Econ., 41(141), pp.406-423.

Colclough, C. (2008).Gender Equality in Education-Increasing the Momentum for Change. RECOUP Policy Brief No. 2.

Cotula, L., Toulmin C., and Hesse C. (2004). Land Tenure and Administration in Africa: Lessons of Experience and Emerging Issues. London: International Institute for Environment and Development.

Cotula, L., Vermeulen, S., Leonard, R., and Keeley, J. (2009). Land Grab or Development Opportunity? Agricultural Investment and International Land Deals in Africa. Rome/London: IIED/FAO/IFAD.

Daley, E. (2011). Gendered Impacts of Commercial Pressures on Land. Rome, Italy: ILC.

Daley E. and Pallas S. (2014). Women and land deals in Africa and Asia: Weighing the implications and changing the game. Feminist Economics. 20(1), pp. 178-201, London: Taylor Francis. Available online at http://dx.doi.org/10.1080/135457 01.2013.860232. Accessed April 16, 2014.

de Soto, H. (2001). The mystery of capital: Why capitalism triumphs in the West and fails everywhere else. New York: Basic Books.

Deneulin, S. and Shahani L. (2009). An introduction to the human development and capability approach: Freedom and agency. Otawa: IDRC e-book. ISBN 978-1-55250470-3.

Gasu, J. and Agbley, G.K. (2015). Land deals, dispossession and the threat to peasant livelihood in northern Ghana. In In-country determinants and implications of foreign land acquisitions. E. Osabuohien (ed.). Hershey PA: IGI Global, pp.3o6321.

Graziano da Silva, J. (2012). Director General of Food and Agriculture Organization of The United Nations Land Grabbing II International Academic Conference, Ithaca United States: Cornell University.

Holden, S.T., Otsuka K. and Place F.M. (2009). The emergence of Land markets in Africa: Assessing the impacts on poverty, equity and efficiency. Washington DC: Resources for the Future.

International Land Coalition (2011). Tirana Declaration. Available online at http:// www.landcoalition.org/sites/default/files/aom11/Tirana_Declaration_ ILC_2011_ENG.pdf. Accessed on March 21. 2014. 
Kabeer, N., and Van Anh T.T. (2014). Leaving the rice fields, but not the countryside: Gender, livelihoods diversification, and pro-poor growth in rural Vietnam. Shahra Razavi (ed.) In: Shifting burdens: Gender and agrarian change under neoliberalism. UNRISD, Boulder: Kumarian Press.

Lund, C. (2011). Property and citizenship: Conceptually connecting land rights and belonging in Africa. Africa Spectrum. 46(3), pp. 71-75.

Mason, J. (1993). The Indigenous People, the State and Alienation: a case study of Mole National Park, Northern Region. Unpublished MSc Thesis University of Guelph, Canada.

Moyo, S. (2008). African land questions, agrarian transitions and the State: Contradictions of neoliberal land reforms. Dakar: CODESRIA.

Musembi, N.C. (2007). de Soto and land relations in rural Africa: breathing life into dead theories about property rights. Third World Quarterly, 28(8), pp. 1457 1478 .

Neuman, W.L. (2012). Basics of social research: Qualitative and quantitative approaches. ( $3^{\text {rd }}$ Ed.). Boston: Pearson.

Nikoi, A.R. (2010). Human Geography for Senior High Schools. Accra:Aki Ola Publications.

Nyari, B. (2008). Biofuel and land grabbing in northern Ghana. Accessed on July 32014 from http://www.rainforestrescue.org/news/1062/biofuel-land-grabbing-innorthern-ghana.

Razavi, S. (ed.). (2014). Shifting Burdens: Gender and agrarian change under neoliberalism. Boulder: Kumarian Press.

Robeyns, I. (2003). The capability approach: An interdisciplinary approach. Training course preceding the $3^{\text {rd }}$ International Conference on the Capability Approach, Pavia, $6^{\text {th }}$ September 2003.

Robson, C. (2006). Real World Research. ( $2^{\text {nd }}$ Ed.). Malden, MA: Blackwell.

Sen, A. (1999). Development as freedom. New York: Oxford University Press.

Tsikata, D., and Yaro, J.A. (2011). Land market liberalization and trans-national commercial land deals in Ghana since the 1990s. Paper presented at the international conference on "Global Land Grabbing", organised by Land Deals Politics Initiative (LDPI) in collaboration with Journal of Peasant Studies and hosted by Future Agricultures Consortium at the Institute of Development Studies Sussex from 6-8 April 2011.

van der Geest, K. (2011). North-South migration in Ghana: What role for environnent? International Migration. 49(1) pp. 69-94. 
Wisborg, P. (2012). Justice and Sustainability: Resistance and innovation in transnational land deal in Ghana. Paper presented at the World Bank annual conference on land and poverty 2012. World Bank, Washington DC, April 23rd - 26th, 2012.

World Bank (2014). Land and Food Security. Avalable online at http://www.worldbank. org/en/topic/agriculture/brief/land-and-food-security.

Yamano, T., Place, F.M., Nyangena, W., Wanjiku, J. and Otsuka, K. (2009). Efficiency and equity impacts of land markets in Kenya. In The emergence of land markets in Africa: Assessing the impacts on poverty, equity and efficiency. S.T. Holden, K. Otsuka \& F.M. Place (eds.). Washington DC: Resources for the Future.

Yaro, J.A. (2013). Neoliberal globalization and evolving traditional institutions: implications for access to resources in rural northern Ghana. Review of African Political Economy, 40(137), pp. 410-427.

Yiran, G.A.B., Kusimi, J.M., and Kufugbe, S.K. (2012). A synthesis of remote sensing and local knowledge approaches in assessing land degradation in the Bawku East District-Ghana. International Journal of Applied Earth Observation and Geoinformation. 14 (1), pp. 204-213.

\section{Full Disclosure}

This paper was originally submitted to the CODESRIA Gender Institute on Gender and Land Tenure, $5^{-20^{\text {th }}}$ June 2014 in Dakar. Funding is by CODESRIA, Dakar and the author's personal resources. 